\title{
Comparison of spirometry and impulse oscillometry in methacholine challenge test for the detection of airway hyperresponsiveness in adults
}

\author{
Masoud \\ NAZEMIYAH $^{\mathbf{1}}$ (ID) \\ Khalil ANSARIN ${ }^{\mathbf{1}}$ (ID) \\ Masoud NOURI- \\ VASKEH $^{2}$ (ID) \\ Tohid SADEGI $^{1}$ (ID) \\ Akbar SHARIFI $^{1}$ (ID)
}

\footnotetext{
${ }^{1}$ Tuberculosis and Lung Disease Research Center, Tabriz University of Medical Sciences, Tabriz, Iran

1 Tebriz Tıp Bilimleri Üniversitesi, Tüberküloz ve Akciğer Hastalıkları Araştırma Merkezi, Tebriz, Iran

${ }^{2}$ Immunology Research Center, Tabriz University of Medical Sciences, Tabriz, Iran

${ }^{2}$ Tebriz Tıp Bilimleri Üniversitesi, Immünoloji Araştırma Merkezi, Tebriz, Iran

${ }^{3}$ Network of Immunity in Infection, Malignancy and Autoimmunity (NiiMA), Universal Scientific Education and Research Network (USERN), Tehran, Iran

${ }^{3}$ Uluslararası Bilimsel Ĕ̆itim ve Araştırma A $\breve{g} ı$ (USERN), Enfeksiyonda Bağışıklık A $\breve{g} ı$, Malignite ve Otoimmünite, Tahran, Iran
}

Cite this article as: Nazemiyah $M$, Ansarin $K$, NouriVaskeh M, Sadegi T, Sharifi A. Comparison of spirometry and impulse oscillometry in methacholine challenge test for the detection of airway hyperresponsiveness in adults. Tuberk Toraks 2021;69(1):1-8.

\section{Yazışma Adresi (Address for Correspondence)}

\section{Dr. Akbar SHARIFI}

Tabriz University of Medical Sciences,

Tuberculosis and Lung Disease Research Center, TABRIZ - IRAN

e-mail: ak.sharif1349@gmail.com

\footnotetext{
CCopyright 2021 by Tuberculosis and Thorax.
}

Available on-line at www.tuberktoraks.org.com

\section{ABSTRACT}

Comparison of spirometry and impulse oscillometry in methacholine challenge test for the detection of airway hyperresponsiveness in adults

Introduction: Airway hyper-responsiveness (AHR) is a characteristic feature of asthma. The aim of this study was to compare the impulse oscillometry (IOS) and spirometry to methacholine for AHR detection among individuals with clinically hyper-reactive airway disease suggestive of bronchial asthma and baseline spirometry were normal.

Materials and Methods: Adults with symptoms suggestive of AHR and normal baseline spirometry test were selected. The short protocol of methacholine challenge test (MCT) was performed for all subjects using IOS and spirometry simultaneously. The primary endpoint was to compare the methacholine dosage causing a $20 \%$ drop in forced expiratory volume in one second $\left(F E V_{1}\right)$, with methacholine dosage that causing $40 \%$ increasing the baseline respiratory resistance at 5 hertz $\left(R_{5}\right)$, as measured by IOS.

Results: A total of 235 participants were analyzed, 184 (78.2\%) had positive test results with $R 5$, while 81 (34.4\%) had positive $M C T$ results with FEV . The sensitivity and specificity of MCT with R5were $87.3 \%, 64.6 \%$, and MCT with 
FEV1 were $39.1 \%, 85.4 \%$, respectively. The area under the receiver operating characteristic (ROC) curve was greater at lower doses of MCT at R5, (AUROC: $0.653 ; p=0.01$ ).

Conclusion: The results showed higher sensitivity, negative predictive value, and earlier response of the short protocol of MCT with IOS, compared to MCT with spirometry. Our study suggested the utility of IOS in addition to conventional spirometry as a method of choice in MCT for detection of AHR.

Key words: Airway hyper-responsiveness; impulse oscillometry system; respiratory function test; methacholine challenge test; spirometry

Öz

Yetişkinlerde hava yolu aşırı duyarlılığının tespiti için metakolin provokasyon testinde spirometri ve impuls osilometrinin karşılaştırılması

Giriş: Hava yolu hiperreaktivitesi (HHR) astımın karakteristik bir özelliğidir. Bu çalışmada amaç, bronşiyal astımı düşündüren klinik olarak HHR olan ve başlangıç spirometresi normal olan bireylerde, HHR tespiti için impuls osilometri (IOS) ve metakolin provokasyon testlerinin karşılaştırılmasıdır.

Materyal ve Metod: Çalışmaya HHR'yi düşündüren semptomları olan ve normal başlangıç spirometri testi olan yetişkinler seçildi. Metakolin provokasyon testinin (MPT) kısa protokolü, eş zamanlı olarak IOS ve spirometri kullanılarak tüm hastalara uygulandı. Birincil son nokta, bir saniyede zorlu ekspiratuar hacimde \%20'lik bir düşüşe (FEV ${ }_{1}$ ) neden olan metakolin dozunu, IOS ile ölçülen bazal solunum rezistansını gibi 5 hertz'de (R5) \%40 artıran metakolin dozajıyla karşılaştırmaktı.

Bulgular: Çalışmada toplam 235 hasta değerlendirildi. Hastaların 184'ü (\%78,2) R5 ile pozitif test sonuçlarına sahipken, 81'i (\%34,4) FEV ile pozitif MPT sonuçlarına sahipti. MPT'nin R5 ile duyarlılığı ve özgüllüğü sırasıyla \%87,3,\%64,6 ve FEV ile MPT \%39,1, \% 85,4 idi. ROC analizinde eğri altında kalan alan, R5'te daha düşük MPT dozlarında daha büyüktü (AUROC: 0,653; $p=0,01)$.

Sonuç: Sonuçlar, spirometri ile MPT'ye kıyasla, IOS ile MPT'nin kısa protokolünün daha yüksek duyarlılığı, daha yüksek negatif prediktif değeri ve daha erken yanıtı olduğunu gösterdi. Çalışmamızın, HHR'nin saptanması için MPT'de tercih edilen bir yöntem olarak geleneksel spirometriye ek olarak IOS'un kullanımını önermektedir.

Anahtar kelimeler: Hava yolu aşırı duyarlılığı; impuls osilometri sistemi; solunum fonksiyon testi; metakolin yükleme testi; spirometri

\section{INTRODUCTION}

Airway hyper-responsiveness (AHR) is a characteristic feature of asthma. AHR assessment is part of the investigation in patients with chronic cough, recurrent wheezing, and shortness of breath $(1,2)$. Commonly, AHR is examined by inhalation of methacholine and assessment of the patient's response through spirometry (3). A positive methacholine challenge test (MCT) is typically defined as a $\geq 20 \%$ decrement in forced expiratory volume in one second $\left(\mathrm{FEV}_{1}\right)$ at relatively lower doses of methacholine (e.g., 4-8 mg/mL PC20) (4).

The current standard MCT requires repeated spirometry following the application of increasing doses of methacholine. However, this test requires patient cooperation and can be time-consuming, leading to the prolonged exposure of respiratory laboratory technicians to methacholine $(5,6)$. An alternative outcome measure for hyper-responsiveness are respiratory resistance and reactance, which can be measured more conveniently by impulse oscillometry (IOS), compared to body plethysmography.
MCT with IOS has been suggested as a new alternative method for the evaluation of AHR $(7,8)$. Previous studies have revealed significant and acceptable correlation between $40 \%(9,10)$ to $50 \%(11,12)$ increment in baseline values of respiratory resistance at $5 \mathrm{~Hz}$ in $\mathrm{IOS}$ and $20 \%$ decline in baseline $\mathrm{FEV}_{1}$ in spirometry to detect of AHR.

Therefore, the lowest value of $40 \%$ increment of resistance in IOS used by several previous investigators was adopted as the critical value in this study, which will probably increase the sensitivity of the test with lower specificity than fifty percent.

To the best of our knowledge, there are no adequate studies comparing MCT with IOS and spirometry for the detection of clinical AHR, especially in adults. In fact, previous studies have mainly compared these two methods in patients with diagnosed asthma. Considering the relative advantages and disadvantages of these two methods, in this study, we aimed to compare their efficacies from different aspects of the detection of AHR. 


\section{MATERIALS and METHODS}

\section{Study Design}

In this prospective study, adults (age $>15$ years) with symptoms (such as cough, shortness of breath, or wheezing) suggestive to bronchial asthma and normal baseline spirometry were selected by a pulmonologist at the Tuberculosis and Lung Diseases Research Center of Tabriz University of Medical Sciences.

The exclusion criteria were as follows: history of upper respiratory tract infection in the past four weeks; history of allergic rhinitis; history of tobacco smoking at the time of referral or smoking (be smokefree for less than 1 year); history of heart failure; clinical gastroesophageal reflux diseases, chronic sinusitis, known pulmonary diseases, previous thoracic surgery, pregnancy, breastfeeding, recent myocardial infarction and patient with positive drug history with respiratory side effects (e.g., beta-blockers and angiotensin-converting enzyme inhibitors). In addition, patients with poor cooperation during testing process were excluded.

MCT with spirometry and IOS were conducted using theMaster Screen device (Jaeger, Würzburg, Germany) in all patients at the pulmonary function laboratory of Madani Hospital affiliated with Tabriz University of Medical Sciences.

Using the standard aerosol provocation system with a jet-type nebulizer (APS, Viasys Healthcare $\mathrm{GmbH}$, Höchberg, Germany), incremental doses of methacholine were automatically nebulized to the airways. The subjects were exposed to increasing doses of inhaled methacholine at concentrations of methacholine up to $8 \mathrm{mg} / \mathrm{mL}$ or less in four stages. One minutes after each exposure, respiratory resistance was measured by IOS (airway reactance unable detected during MCT), and then, $\mathrm{FEV}_{1}$ was measured by spirometry the process was continued after and beyond the $40 \%$ increase in $5 \mathrm{~Hz}$ respiratory resistance was reached in IOS and so both arms were conducted similarly. A $20 \%$ reduction in $\mathrm{FEV}_{1}$ and a $\geq 40 \%$ increase in $R_{5}$ were considered as positive results.

All of the participants were treated with ICS, fluticasone (125 $\mu \mathrm{g} /$ puff; GSK Pharmaceutical Co., London, UK) by use of spacer. Patients who improved symptomatically in cough, dyspnea and wheezing by ICS for two months were considered as responders, while the rest of the patients were considered as non-responders. The two methods of detection were compared based on the lowest methacholine concentration needed to meet the target criteria of airway hyper-reactivity in each method.

This study was approved by the Institutional Review Board (IRB) of Tuberculosis and Lung Diseases Research Center of Tabriz University of Medical Sciences (Approval No: 9220, Date: 17 December 2016). Patients were informed about the research and signed a written consent.

\section{Statistical Analysis}

Quantitative data are presented as mean \pm standard deviation (SD) or as percentage for normally distributed data. Median values were measured for non-normally distributed data. Also, qualitative data were presented as frequency and percentage. Comparisons between the groups were performed using Student's t-test and Mann-Whitney $U$ test, and correlations were evaluated using Spearman's or Pearson's statistical tests. Mean values with $95 \%$ confidence interval (Cl) were measured to indicate the diagnostic value (sensitivity, specificity, and positive and negative predictive values) of each method. The receiver operating characteristics (ROC) curve was also plotted, and areas under the ROC curve (AUROC) were compared. In this study, we used SPSS version 21 (Chicago, IL, USA) software for the data analysis, and $\mathrm{p}<0.05$ was considered statistically significant.

\section{RESULTS}

A total of 253 patients were enrolled to the study. Eighteen participants did not complete the study; five participants were excluded due to severe coughing and three patients had exaggerated experience of shortness of breath, and the other ten participants were excluded due to loss of follow-up.

Finally, 235 participants, consisting of 113 (48.6\%) males and 122 (51.4\%) females, were analyzed. All of the patients presented with coughing, dyspnea and chest tightness. The characteristics of the participants are presented in Table 1 . The frequency of negative and positive response at incremental doses of methacholine in both MCT methods and absolute changes in $\mathrm{FEV}_{1}$ and respiratory resistance at 5 hertz at different doses of methacholine are shown in Tables 2 and 3.

The sensitivity, specificity, negative predictive value (NPV) and positive predictive value (PPV) of two 
Table 1. Patients' characteristics

\begin{tabular}{|c|c|c|c|}
\hline Characteristic & Responders & Non-responders & p \\
\hline Age (year) & $36.1 \pm 11.9$ & $34.0 \pm 13.9$ & 0.38 \\
\hline Height $(\mathrm{cm})$ & $167 \pm 14.9$ & $165.4 \pm 9.7$ & 0.57 \\
\hline Weight (Kg) & $72.4 \pm 14.9$ & $70.4 \pm 15.7$ & 0.51 \\
\hline $\mathrm{BMI}\left(\mathrm{kg} / \mathrm{m}^{2}\right)$ & $26.1 \pm 7$ & $25.7 \pm 5.4$ & 0.75 \\
\hline Smoking & - & - & - \\
\hline Family history & - & - & - \\
\hline Medical history & - & - & - \\
\hline $\mathrm{FEV}_{1}(\mathrm{~L})$ & $3.39 \pm 0.7$ & $3.26 \pm 0.7$ & 0.57 \\
\hline Resistance at $5 \mathrm{~Hz}(\mathrm{KPa} /(\mathrm{L} / \mathrm{s}))$ & $3.27 \pm 0.58$ & $3.25 \pm 0.23$ & 0.68 \\
\hline
\end{tabular}

Table 2. Frequency of Negative and Positive Response at incremental doses of methacholine detected by impulse oscillometric versus spirometric method Impulse oscillometry

\begin{tabular}{|lcccc}
\hline & \multicolumn{3}{c}{ Impulse oscillometry method } \\
\hline Spirometric method & Not detected & Not detected & Detected & Total \\
& Detected & 46 & 110 & 154 \\
& Total & 51 & 76 & 81 \\
& & 184 & 235 \\
\hline
\end{tabular}

Table 3. Absolute changes in FEV 1 and airway resistance at 5 hertz at different doses of methacholine

\begin{tabular}{|c|c|c|c|c|}
\hline & Minimum & Maximum & Mean & Std. Deviation \\
\hline $\mathrm{FEV}_{1}$ at $1(\mathrm{~L})$ & 1.68 & 5.47 & 3.38 & 0.73 \\
\hline $\mathrm{FEV}_{1}$ at $2(\mathrm{~L})$ & 1.61 & 5.25 & 3.34 & 0.79 \\
\hline $\mathrm{FEV}_{1}$ at $3(\mathrm{~L})$ & 1.29 & 9.14 & 3.34 & 0.90 \\
\hline $\mathrm{FEV}_{1}$ at $4(\mathrm{~L})$ & 1.65 & 7.28 & 3.33 & 0.86 \\
\hline $\mathrm{R}_{5}$ at $1(\mathrm{KPa} /(\mathrm{L} / \mathrm{s}))$ & 1.93 & 9.65 & 4.05 & 1.49 \\
\hline $\mathrm{R}_{5}$ at $2(\mathrm{KPa} /(\mathrm{L} / \mathrm{s}))$ & 1.95 & 11.52 & 4.33 & 1.62 \\
\hline $\mathrm{R}_{5}$ at $3(\mathrm{KPa} /(\mathrm{L} / \mathrm{s}))$ & 2.03 & 11.22 & 4.67 & 1.75 \\
\hline $\mathrm{R}_{5}$ at $4(\mathrm{KPa} /(\mathrm{L} / \mathrm{s}))$ & 2.31 & 15.44 & 5.42 & 2.32 \\
\hline
\end{tabular}

Table 4. The sensitivity, specificity, Negative predictive value (NPV) and positive predictive value (PPV) of the two methods in detection of AHR

\begin{tabular}{|lccccc|}
\hline Method of test & Sensitivity & Specificity & NPV & PPV & p \\
\hline IOS & $87.3 \%$ & $64.6 \%$ & $87.3 \%$ & $64.6 \%$ & $\leq 0.001$ \\
Spirometry & $39.1 \%$ & $85.4 \%$ & $30.1 \%$ & $89.7 \%$ & 0.001 \\
\hline
\end{tabular}

methods for AHR detection are shown in Table 4. The time intervals to appropriate positive responses to MCT with IOS and spirometric method, using different doses of methacholine and absolute changes in $R_{5}$ at IOS and $\mathrm{FEV}_{1}$ are presents in Table 5 and 6 .
The greatest AUROC of MCT occurred in first stage of IOS (AUROC $=0.653 ; 95 \% \mathrm{Cl}: 0.552-0.753 ; \mathrm{p}=$ $0.01)$. ROC measurements of the two methods are demonstrated in Table 7. 
Table 5. The results of absolute changes in R5 at IOS and FEV1 at different doses of MCT

\begin{tabular}{|lcccc|}
\hline FEV $_{\mathbf{1}}(\mathbf{L})$ & $\mathbf{1}^{\text {st }}$ Dose & $\mathbf{2}^{\text {nd }}$ Dose & $\mathbf{3}^{\text {rd }}$ Dose & $\mathbf{4}^{\text {th }}$ Dose \\
\hline Mean & 3.371 & 3.329 & 3.326 & 3.313 \\
Std deviation & 0.735 & 0.779 & 0.905 & 0.857 \\
Min-Max & $1.67-5.47$ & $1.61-5.25$ & $1.29-9.14$ & $1.65-7.28$ \\
$\mathrm{R}_{5}$ at IOS $(\mathrm{KPa} /(\mathrm{L} / \mathrm{s}))$ & & & 4.372 & 4.735 \\
Mean & 3.261 & 4.070 & 1.637 & 1.763 \\
Std deviation & 0.588 & 1.508 & $1.95-11.52$ & $2.03-11.22$ \\
Min-Max & $2.38-7.27$ & $1.93-9.65$ & & \\
\hline
\end{tabular}

Table 6. The frequency of participants detected by spirometric versus oscillometric method at different methacholine doses

\begin{tabular}{|lccccccc} 
& \multicolumn{7}{c}{ Impulse Oscillometric Method } \\
\cline { 2 - 6 } Spirometric Method & Negative & $\mathbf{1}^{\text {st }}$ Dose & $\mathbf{2}^{\text {nd }}$ Dose & $\mathbf{3}^{\text {rd }}$ Dose & $\mathbf{4}^{\text {th }}$ Dose & Total \\
\hline Negative & 46 & 28 & 23 & 24 & 33 & 154 \\
$1^{\text {st }}$ Dose & 1 & 18 & 3 & 5 & 3 & 28 \\
$2^{\text {nd }}$ Dose & 1 & 15 & 2 & 2 & 3 & 21 \\
$3^{\text {rd }}$ Dose & 1 & 4 & 3 & 3 & 0 & 15 \\
$4^{\text {th }}$ Dose & 2 & 9 & 36 & 37 & 37 & 17 \\
Total & 51 & 74 & 37 & 235 \\
\hline
\end{tabular}

Table 7. The Receiver operating characteristic (ROC) curve with IOS method at different doses of methacholine

\begin{tabular}{|c|c|c|c|c|c|}
\hline \multirow[b]{2}{*}{ R5 at IOS } & \multirow[b]{2}{*}{ Area Under Curve } & \multirow[b]{2}{*}{ Standard Error } & \multirow[b]{2}{*}{$\mathbf{p}$} & \multicolumn{2}{|c|}{$95 \%$ Confidence Interval } \\
\hline & & & & Lower Bound & Upper Bound \\
\hline $1^{\text {st }}$ Dose & 0.653 & 0.051 & 0.017 & 0.552 & 0.753 \\
\hline $2^{\text {nd }}$ Dose & 0.623 & 0.053 & 0.055 & 0.519 & 0.727 \\
\hline $3^{\text {rd }}$ Dose & 0.628 & 0.056 & 0.046 & 0.517 & 0.738 \\
\hline $4^{\text {th }}$ Dose & 0.634 & 0.058 & 0.037 & 0.519 & 0.748 \\
\hline
\end{tabular}

In the current study, positive MCT, according to ROC curve with $\mathrm{AUROC}=0.446$, the point of relatively higher specificity, $66.7 \%$ specificity and $21.7 \%$ sensitivity of MCT, the $20 \%$ or more drop of $\mathrm{FEV}_{1}$ from baseline $\mathrm{FEV}_{1}$ was associated with $43.8 \%$ increase in $\mathrm{R}_{5}$.

According to the follow-up visit, $82.2 \%$ of the patients were responders to ICS and the rest of the subjects who had symptoms compatible with reactive airway disease with no response to steroid therapy. Mean $\mathrm{FEV}_{1}$ in the original test was compared between the two groups of responders and non-responders to ICS. Mean $\mathrm{FEV}_{1}$ in the non-responder and responder groups was 3.26 \pm 0.7 Liter and 3.39 \pm 0.7 Liter, respectively; the difference between the groups was not significantly different which revealed original pulmonary function not significant difference between these two groups. After MCT, FEV decreased in both groups of responders and non-responders to ICS therapy; however, there was no significant difference between the two groups $(p=0.58)$.

\section{DISCUSSION}

In this study, the base $\mathrm{FEV}_{1}$ was not significantly different between the two groups, which shows precise indication for provocative test. Moreover, we demonstrated that the sensitivity and NPV of IOS method was higher than the spirometric method and the former method could detect AHR at lower doses of methacholine. 
The sensitivity and specificity of standard MCT using the spirometric method have been reported nearly $70-80 \%$ and $90 \%$, respectively (13). Therefore, a significant number of patients with AHR may remain undetected using this method (13). Moreover, respiratory resistance can be measured more conveniently by IOS, compared to spirometry (14-16). IOS has been extensively studied in the diagnosis of obstructive airway diseases (17-19). However, the application of this method in bronchial provocation tests has been evaluated in a limited number of studies and only for established cases of bronchial asthma $(12,20)$. Since the increase in airway resistance is secondary to increased bronchial smooth muscle tone and precedes the reduction of $\mathrm{FEV}_{1}$ after methacholine inhalation, measurement of respiratory resistance, based on pressure flow characteristics, may be more sensitive than the measurement of spirometric values (21). Accordingly, in the current study, NPV of MCT with IOS was significantly higher than that of standard spirometric MCT (22).

The reported sensitivity of the standard spirometric method for the detection of AHR ranges from $51 \%$ to $100 \%$ (23). However, it should be noted that in the current study, the sensitivity of standard MCT in the detection of AHR was even lower than previous reports $(39.1 \%)$. This finding may be related to the fact that previous studies have mostly evaluated AHR in patients diagnosed with asthma. Despite this, demographic characteristics of study populations may play a role $(23,24)$.

In this study, 81 out of 235 patients showed positive MCT results by the spirometric method while 184 patients met the criteria for positive MCT by the IOS method. In $55.9 \%$ of the patients with negative MCT results based on spirometry, AHR was detected using IOS. This finding is consistent with previous studies indicating higher sensitivity and rather high specificity of IOS in detection of AHR (25). In the current study, the sensitivity and specificity of IOS in detecting AHR were $87.3 \%$ and $64.6 \%$, respectively, compared to the standard technique. Won Yoon et al. (20) have reported the sensitivity and specificity of IOS in detecting AHR to be $57 \%$ and $65 \%$, respectively. Moreover, in a study by Sumino et al. (23), the total sensitivity and specificity of MCT with spirometry were $51-100 \%$ and $44-100 \%$, respectively. Another study by Nizar Najiet al. has shown that IOS is more sensitive than the plethysmographic method for the detection of airway resistance changes following allergen and methacholine exposure (22). These studies have revealed that MCT with IOS is more sensitive but less specific than the spirometric method for the detection of AHR.

Another major difference between the two methods in the present study was the detection power of AHR at lower doses of methacholine, compared to the spirometric method. Of the 184 patients detected by the oscillometric method, 74 patients were detected in the first stage of MCT, while only 28 out of 81 patients with positive MCT based on the spirometric method showed positive results in the first stage. This relationship was also confirmed by the comparison of AUROC in different stages of MCT between the two methods, which showed the highest ARUC in the first stage of IOS. This finding shows the greater potential for the detection of AHR in the early stage of MCT in patients suspected of AHR.

The present findings suggest that MCT with IOS has high sensitivity compared to spirometric method. The higher sensitivity of MCT with IOS, compared to standard MCT, may be explained by the well-known Poiseuille's law, which describes that the flow of any fluid in a tube is determined by the tube resistance, which is determined especially by tube diameter. Therefore, any increase in resistance is reflected by a decrease in flow and direct measurement of resistance may be more sensitive than flow measurement for the detection of tube narrowing $(21,26)$. The identification of AHR with lower doses of methacholine reduces the exposure of the patient and operator to methacholine. Although the increase in sensitivity of any test may reduce its specificity, in the present study, the specificity of IOS was more than the standard method $(22,27,28)$. Therefore, clinical implications and possible applications of these findings need further elucidation in future studies. This study had some limitations such as sample size. Moreover, we did not follow-up the patients to measure the parameters in the long-time.

\section{CONCLUSION}

This study demonstrated that MCT with IOS had higher sensitivity and rather high specificity compared to standard MCT with spirometry. These findings suggest that IOS may be a more efficient tool than the spirometric method for the detection of AHR. 
Ethical Committee Approval: This study was approved by the Institutional Review Board (IRB) of Tuberculosis and Lung Diseases Research Center of Tabriz University of Medical Sciences (Approval No: 9220, Date: 17 December 2016).

\section{CONFLICT of INTEREST}

The authors of this meta-analysis declare that they have no conflict of interest.

\section{AUTHORSHIP CONTRIBUTIONS}

Concept/Design: AS, MN

Analysis/Interpretation: KA, MNV

Data Acqusition: MN, TS

Writing: MN, MNV, AS

Clinical Revision: KA, TS

Final Approval: All of authors

\section{REFERENCES}

1. Comberiati P, Katial RK, Covar RA. Bronchoprovocation testing in asthma: an update. Immunol Allergy Clin North Am 2018; 38(4): 545-71.

2. Horak F, Doberer D, Eber E, Horak E, Poh/ W, Riedler J, et al. Diagnosis and management of asthma - statement on the 2015 GINA Guidelines. Wien Klin Wochenschr 2016; 128(15-16): 541-54.

3. Chapman DG, Irvin CG. Mechanisms of airway hyperresponsiveness in asthma: the past, present and yet to come. Clin Exp Allergy 2015; 45(4): 706-19.

4. Crapo RO, Casaburi $R$, Coates AL, Enright PL, Hankinson $J L$, Irvin CG, et al. Guidelines for methacholine and exercise challenge testing-1999. This official statement of the American Thoracic Society was adopted by the ATS Board of Directors, July 1999. Am J Respir Crit Care Med 2000; 161(1): 309-29.

5. Coates AL, Wanger J, Cockcroft DW, Culver BH, Diamant Z, Gauvreau G, et al. ERS technical standard on bronchial challenge testing: general considerations and performance of methacholine challenge tests. Eur Respir J 2017; 49(5): 1601526.

6. Schwartz N, Grossman A, Levy Y, Schwarz Y. Correlation between eosinophil count and methacholine challenge test in asymptomatic subjects. J Asthma 2012; 49(4): 33641.

7. Hoen AG, Li J, Moulton LA, O'Toole GA, Housman ML, Koestler DC, et al. Associations between Gut microbial colonization in early life and respiratory outcomes in cystic fibrosis. J Pediatr 2015; 167(1): 138-47.

8. Arikoglu T, Unlu A, Yildirim DD, Kuyucu S. The airway hyperresponsiveness to methacholine may be predicted by impulse oscillometry and plethysmography in children with well-controlled asthma. J Asthma 2018; 55(11): 1166-73.
9. Broeders ME, Molema J, Hop WC, Folgering HT. Bronchial challenge, assessed with forced expiratory manoeuvres and airway impedance. Respir Med 2005; 99(8): 104652.

10. Kalliola S, Malmberg LP, Kajosaari M, Mattila PS, Pelkonen AS, Makela MJ. Assessing direct and indirect airway hyperresponsiveness in children using impulse oscillometry. Ann Allergy Asthma Immunol 2014; 113(2): 166-72.

11. Brashier B, Salvi S. Measuring lung function using sound waves: role of the forced oscillation technique and impulse oscillometry system. Breathe (Sheff) 2015; 11(1): 57-65.

12. Mansur AH, Manney S, Ayres JG. Methacholine-induced asthma symptoms correlate with impulse oscillometry but not spirometry. Respir Med 2008; 102(1): 42-9.

13. Komarow HD, Skinner J, Young M, Gaskins D, Nelson C, Gergen PJ, et al. A study of the use of impulse oscillometry in the evaluation of children with asthma: analysis of lung parameters, order effect, and utility compared with spirometry. Pediatr Pulmonol 2012; 47(1): 18-26.

14. Li Y, Chen Y, Wang P. Application of impulse oscillometry and bronchial dilation test for analysis in patients with asthma and chronic obstructive pulmonary disease. Int J Clin Exp Med 2015; 8(1): 1271-5.

15. Nazemiyeh $M$, Nouri-Vaskeh $M$, Somi MH, Saeedi $E$, Sharifi A. Lung function parameters in patients with gastroesophageal reflux without respiratory symptoms: a case-control study. Gastroenterol Hepatol Bed Bench 2019; 12(4): 287-91.

16. Bickel S, Popler I, Lesnick B, Eid N. Impulse oscillometry: interpretation and practical applications. Chest 2014; 146(3): $841-7$.

17. Piorunek T, Kostrzewska M, Cofta S, Batura-Gabryel H, Andrzejczak P, Bogdanski P, et al. Impulse oscillometry in the diagnosis of airway resistance in chronic obstructive pulmonary disease. Adv Exp Med Biol 2015; 838: 47-52.

18. Wei X, Shi Z, Cui Y, Mi J, Ma Z, Ren J, et al. Impulse oscillometry system as an alternative diagnostic method for chronic obstructive pulmonary disease. Medicine (Baltimore) 2017; 96(46): e8543.

19. Lundblad LKA, Miletic $R$, Piitulainen E, Wollmer P. Oscillometry in chronic obstructive lung disease: in vitro and in vivo evaluation of the impulse oscillometry and tremoflo devices. Sci Rep 2019; 9(1): 11618.

20. Yoon JW, Shin YH, Jee HM, Chang SJ, BaekJH, Choi SH, et al. Useful marker of oscillatory lung function in methacholine challenge test-comparison of reactance and resistance with dose-response slope. Pediatr Pulmonol 2014; 49(6): 521-8.

21. Kaminsky DA. What does airway resistance tell us about lung function? Respir Care 2012; 57(1): 85-96.

22. Naji N, Keung E, Kane J, Watson RM, Killian KJ, Gauvreau GM. Comparison of changes in lung function measured by plethymography and IOS after bronchoprovocation. Respir Med 2013; 107(4): 503-10. 
23. Sumino $K$, Sugar EA, Irvin CG, Kaminsky DA, Shade D, Wei $C Y$, et al. Methacholine challenge test: diagnostic characteristics in asthmatic patients receiving controller medications. J Allergy Clin Immunol 2012; 130(1): 69-75.

24. Peat JK, Salome CM, Woolcock AJ. Factors associated with bronchial hyperresponsiveness in Australian adults and children. Eur Respir J 1992; 5(8): 921-9.

25. Olaguibel JM, Alvarez-Puebla MJ, Anda M, Gomez B, Garcia BE, Tabar Al, et al. Comparative analysis of the bronchodilator response measured by impulse oscillometry (IOS), spirometry and body plethysmography in asthmatic children. I Investig Allergol Clin Immunol 2005; 15(2): 102-6.
26. Kraemer R, Smith HJ, Sigrist T, Giger G, Keller R, Frey $M$. Diagnostic accuracy of methacholine challenge tests assessing airway hyperreactivity in asthmatic patients-a multifunctional approach. Respir Res 2016; 17(1): 154.

27. Short PM, Anderson WJ, Manoharan A, Lipworth BJ. Usefulness of impulse oscillometry for the assessment of airway hyperresponsiveness in mild-to-moderate adult asthma. Ann Allergy Asthma Immunol 2015; 115(1): 17-20.

28. Meraz EG, Nazeran $H$, Ramos CD, Nava P, Diong B, Goldman MD, et al. Analysis of impulse oscillometric measures of lung function and respiratory system model parameters in small airway-impaired and healthy children over a 2-year period. Biomed Eng Online 2011; 10: 21. 